\title{
PRÍSPEVOK K DATOVANIU VZNIKU ROTUNDY SV. JURAJA V NITRIANSKEJ BLATNICI
}

\author{
MARTIN BÓNA - PETER BARTA
}

\begin{abstract}
Abstrakt: Príspevok referuje o výsledku chronometrického výskumu predrománskeho muriva Rotundy sv. Juraja $v$ katastri Nitrianskej Blatnice. Výskum bol realizovaný ${ }^{14} \mathrm{C}$ meraním antropogénneho kalcitu primárnej maltoviny. Priniesol prvý predbežný výsledok ponúkajúci odbornú diskusiu i pracovný podklad pre d'alši chronometrický výskum.
\end{abstract}

Kl'účové slová: Slovensko - Nitrianska Blatnica-predrománska architektúra-sakrálna architektúra $-{ }^{14} \mathrm{C}$ datovanie.

\section{Contribution to the Dating of the Origin of the Rotunda of St. George in Nitrianska Blatnica}

Abstract: This article presents the outcome of chronometric research into pre-Romanesque masonry of the Rotunda of St. George in the Nitrianska Blatnica cadastral zone. The research was conducted by means of ${ }^{14} \mathrm{C}$ measurements of anthropogenic calcite in the primary mortar. The results prompt a specialist discussion and will also serve as groundwork for further chronometric research.

Key words: Slovakia - Nitrianska Blatnica - pre-Romanesque architecture - religious architecture - radiocarbon dating.

\section{Poloha a prehl'ad doterajších poznatkov o vzniku stavby}

Ucelene zachovaný kostol, uvádzaný v literatúre podla dispozičného druhu ako Rotunda sv. Juraja, je situovaný $3,5 \mathrm{~km}$ severne od Nitrianskej Blatnice. Vyníma sa na terasovitom výbežku svahu vrchu Marhát, v južnom pásme Považského Inovca, v polohe zvanej Jurko (455 m n. m.). Pozostáva z ústrednej valcovej lode vnútorného priemeru okolo $7,3 \mathrm{~m}$, východnej apsidy predíženého polkruhového pôdorysu, západnej predstavanej hranolovej veže a kvadratickej južnej

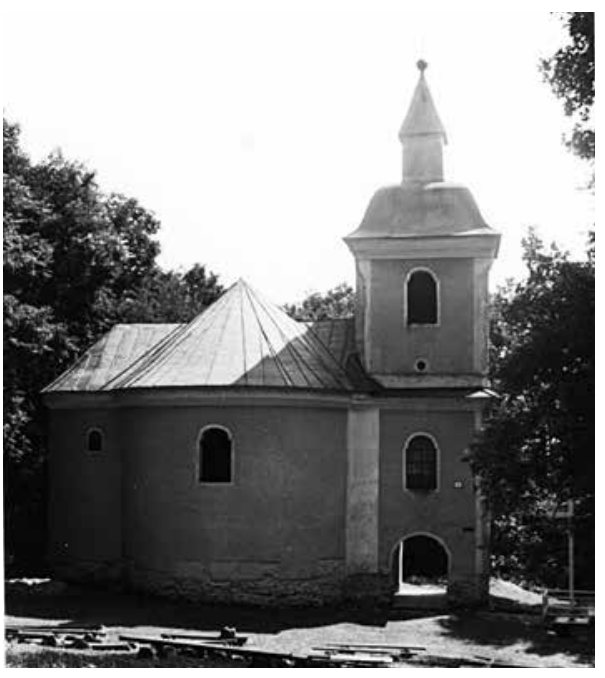

Obr. 1. Nitrianska Blatnica, Rotunda sv. Juraja. Celkový severný pohl'ad na rotundu v roku 2001. Foto M. Bóna.

Abb. 1. Nitrianska Blatnica, St. Georgsrotunde. Nördliche Gesamtansicht der Rotunde im Jahr 2001. Foto M. Bóna. prístavby, slúžiacej kedysi ako pustovňa.

Do 70. rokov 20. storočia bol kostol v pamiatkovej spisbe pokladaný za renesančnú kaplnku z roku 1541 (Forster 1906, 569; Súpis 1968, 375). Prvé indície o románskom pôvode pamiatky priniesol archeologický prieskum AÚ SAV v roku 1970 (A. Ruttkay) a zistovací sondážny pamiatkový výskum SÚPSOP v rokoch 1973-1975 (R. Rejthar, J. Šulcová), ktorým boli v interiéri lode odkryté fragmenty pigmentov indikujúcich prítomnost' nástenných malieb. V časti apsidy bol zároveň identifikovaný jej pôvodný podkovovitý pôdorys, dodatočne upravený na dnešný predížený polkruhový (Rejthar 1975).

Včasnostredoveký pôvod stavby potvrdil následný sondážny archeologický výskum AÚ SAV v Nitre, realizovaný v rokoch 1974 a 1976-1980 pod vedením A. Ruttkaya. Okrem identifikovania včasnostredovekého dvorcového osídlenia z 9.-10. storočia $\mathrm{v}$ susednej polohe Púst' a zaniknutej dediny z 11.-

13. storočia pod rotundou sa výskum sústredil aj na stredoveký cintorín v bezprostrednom okolí rotundy. V zistenej pät’násobnej superpozícii pochovávania bol v tretej vrstve identifikovaný 
hrob s mincou král’a Kolomana (1095-1114), čo umožnilo časové zaradenie najspodnejšej vrstvy hrobov neobsahujúcich datovatel'ný materiál do obdobia najneskôr okolo polovice 11. storočia. Do rovnakého obdobia autor spočiatku datoval aj celú rotundu v rozsahu valcovej lode a apsidy (Ruttkay 1977, 247; 1978, 144). Neskorším zistením stratigrafických vzt’ahov medzi hrobmi a deštrukčnými vrstvami stavebného materiálu dospel A. Ruttkay k záveru, že rotunda bola ešte pred koncom 11. storočia zdeštruovaná a nanovo vymurovaná (Ruttkay 1980, 187). S prihliadnutím na d’alšie nálezy a možné stavebné i regionálne súvislosti s obdobnou vel'komoravskou rotundou v ned’alekom dvorci v Ducovom usúdil, že najspodnejšia základová čast' blatnickej rotundy časovo súvisí s tunajším dvorcom z 9.-10. storočia a vyššia čast' rotundy bola nanovo vymurovaná v priebehu 11. storočia s využitím starších základov (Ruttkay 1989, 347; 1998, 411-412; 2005, 81).

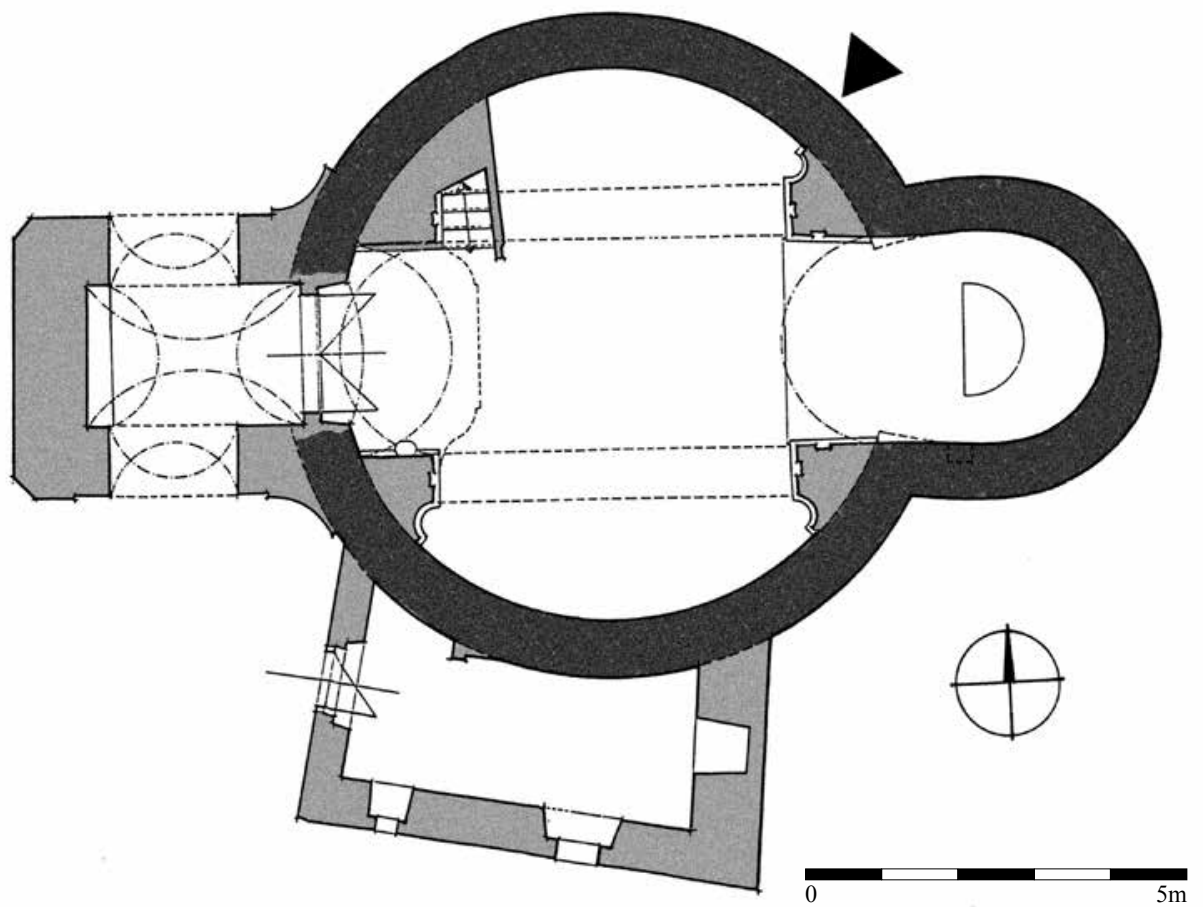

Obr. 2. Nitrianska Blatnica, Rotunda sv. Juraja. Pôdorys rotundy s vyznačením miesta odberu vzorky. S využitím zamerania KSŠPSOP z r. 1973 zakreslil M. Bóna.

Abb. 2. Nitrianska Blatnica, St. Georgsrotunde. Grundriss der Rotunde mit eingezeichneter Probeentnahmestelle. Unter Heranziehung der vom Bezirkszentrum für staatliche Denkmalpflege und Umweltschutz 1973 durchgeführten Vermessung. Zeichnung M. Bóna.

V roku 2001 došlo pri stavebnej úprave pamiatky k opätovnému odkrytiu základových konštrukcií a k osekaniu soklových nesúdržných fasádnych omietok. Tým sa ponúkla nová príležitost' na objasnenie vzt’ahov medzi základovými i nadzákladovými konštrukciami pamiatky. Obhliadkový prieskum realizovaný prvým z autorov tohto príspevku dospel k poznatkom, že horná čast' základového muriva dosadajúceho na severnej strane lode i apsidy na skalné podložie má rovnaký stavebný i spojivový materiál ako nadzákladové murivo odkryté do výšky $1,2 \mathrm{~m}$. Z toho vyplynulo, že najstaršie predrománske murivo rotundy je zachované nielen v základovej, ale i v nadzákladovej úrovni (obr. 3).

1 Obhliadkový prieskum obnažených základových i nadzákladových konštrukcií bol uskutočnený 8.8 . 2001 z podnetu autora, nakol'ko príslušným Pamiatkovým úradom nebol v súvislosti so stavebnou úpravou predpísaný žiaden pamiatkový výskum. 


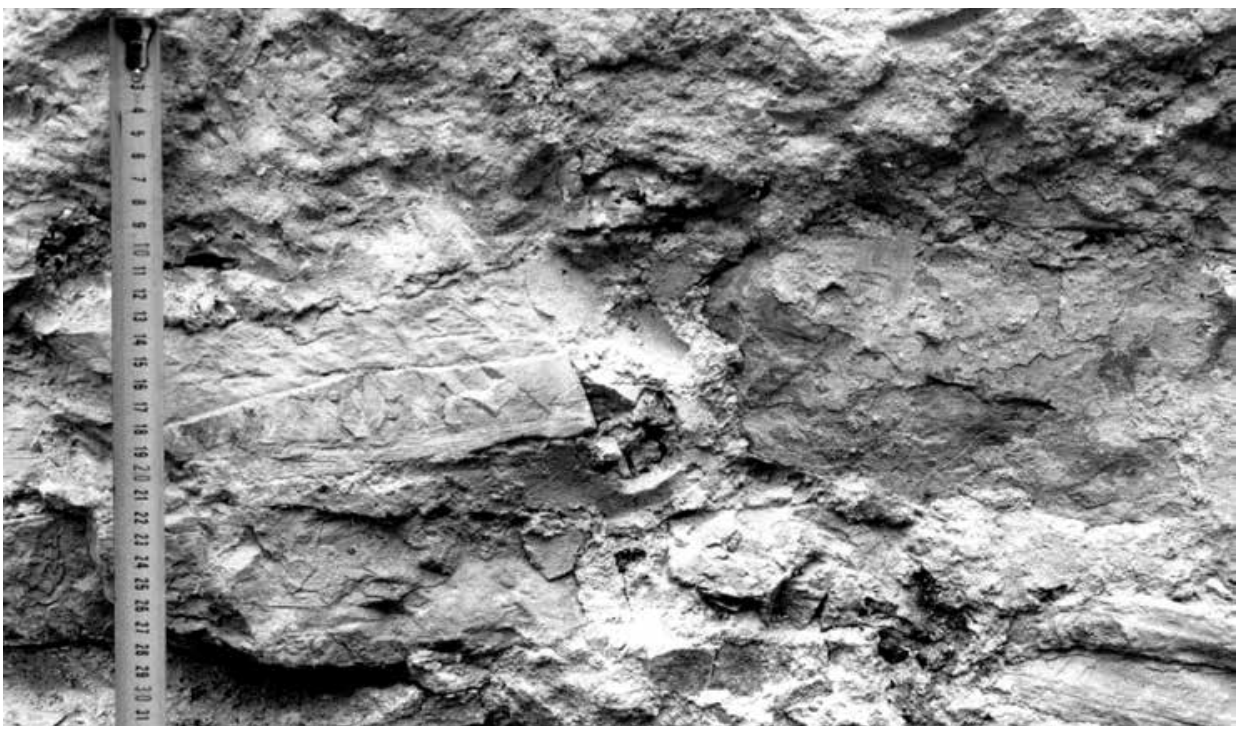

Obr. 3. Nitrianska Blatnica, Rotunda sv. Juraja. Fragmentárne zachovaná primárna povrchová úprava severnej fasády rotundy. Foto M. Bóna, 2001.

Abb. 3. Nitrianska Blatnica, St. Georgsrotunde. Fragmentarisch erhaltene primäre Oberflächenbehandlung der Nordfassade der Rotunde. Foto M. Bóna, 2001.

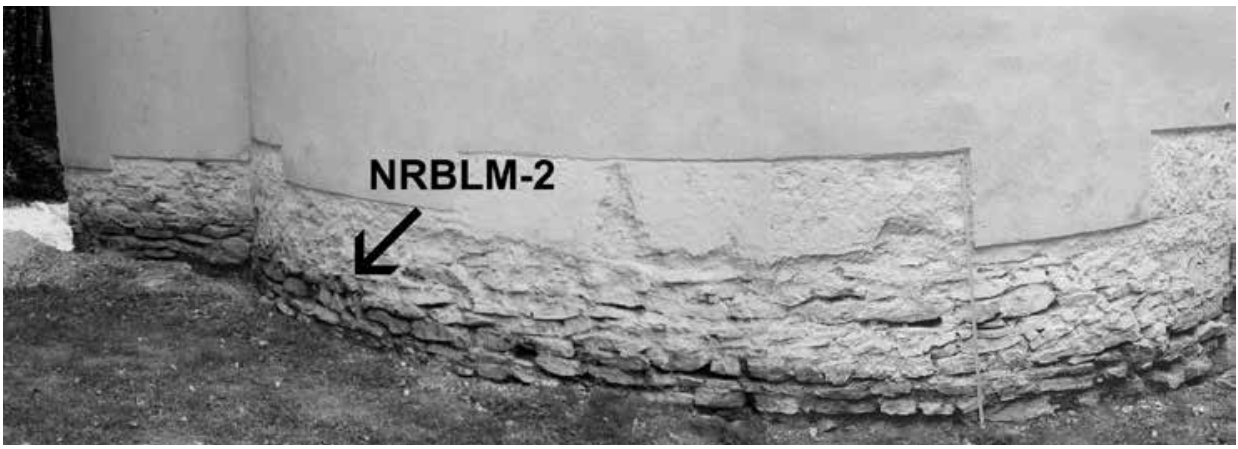

Obr. 4. Nitrianska Blatnica, Rotunda sv. Juraja. Štruktúra predrománskeho muriva severnej fasády rotundy s vyznačením miesta odberu maltovej vzorky. Foto M. Bóna, 2001.

Abb. 4. Nitrianska Blatnica, St. Georgsrotunde. Struktur des vorromanischen Mauerwerks der Rotunde mit eingezeichneter Mörtelprobeentnahmestelle. Foto M. Bóna, 2001.

Napriek výraznému poškodeniu primárnej povrchovej úpravy nadzákladového muriva pri neskorších prestavbách boli v odkrytých situáciách identifikované aj malé zvyšky dohladka roztieranej primárnej maltoviny so zvlneným reliéfom a zárezmi po zatláčaní murárskou lyžicou (obr. 4). Táto povrchová úprava sa v sledovanej časti zachovala najmä v oblastiach styčných škár kamenného muriva, no prechádzala miestami v tenkej vrstve aj na čelá kameňov, takže pôvodne prekrývala väčšinu plochy fasády a obnažené zostali len výraznejšie vystupujúce časti kameňov. V štruktúre základového i nadzákladového muriva vymurovaného z doskovito štiepaného miestneho lomového kameňa boli rozpoznatel'né styčné riadky technologických vrstiev hrubých $35 \mathrm{až} 50 \mathrm{~cm}$. Základové murivo mierne predstupovalo pred líce nadzákladového muriva a v časti apsidy dosahovalo výšku okolo $40 \mathrm{~cm}$. V severnom obvode lode sa híbka založenia v závislosti od pôvodného terénu zvyšovala západným smerom od 45 po $70 \mathrm{~cm} .{ }^{2}$ Počas prieskumu sa zreali-

2 Opísaná híbka pôvodného založenia je definovaná na základe zachovanej výšky predstupujúceho nelícovaného základového muriva a nie vo vzt’ahu k úrovni dnešného terénu. 
zoval aj odber vzoriek primárnej malty a omietkovej úpravy, ktoré neskôr poslúžili na chemicko-technologický rozbor (Zeman 2009) ${ }^{3}$ a ${ }^{14} \mathrm{C}$ datovanie, prezentované v tejto štúdii.

V roku 2009 sa v súvislosti s revíznou obnovou pamiatky zahájil reštaurátorský a architektonicko-historický výskum interiéru a následne aj exteriéru pod vedením J. Doricu a I. Gojdiča. Reštaurátorský výskum spresnil chronológiu vývoja omietkových vrstiev a doložil zachovanost' najstaršieho predrománskeho muriva lode až do výšky 5,6-5,9 m. Preukázal to i cenným objavom primárneho okna v juhozápadnej časti lode, ktoré sa svojím tvarovým a konštrukčným riešením približuje pôvodným oknám predrománskeho kostola v Kostol’anoch pod Tribečom a v Kopčanoch (Dorica 2010, 171-172, 178; 2011, 121-124; 2013, 64-65). ${ }^{4}$ Na základe podobnosti okien i d'alších nálezov sa J. Dorica priklonil k možnosti datovania predrománskeho muriva blatnickej rotundy už do 9 . storočia $(2013,67)$ a v takomto časovom zaradení výstavby zotrval aj A. Ruttkay $(2013,58)$.

Pre exaktné potvrdenie takýchto záverov ale chýba datovatel'ný materiál v najstarších hroboch, rešpektujúcich základy rotundy, pričom stopy osídlenia z 9.-10. storočia, s ktorými by mohla stavba rotundy eventuálne súvisiet', s ňou nemajú stratigrafickú prepojenost'.

Písomné pramene viažuce sa k rotunde pochádzajú až zo 16. storočia a neposkytujú pre jej datovanie bližšiu oporu. Prvá písomná zmienka o tunajšej osade Sarfew pochádza z roku 1185, kedy ju vlastnil Čanádov syn Stojslav z blatnicko-novosadskej vetvy Poznanovcov (Lukačka 2002, 52-53).

\section{Výsledky chronometrického výskumu z rokov 2013-2014}

V snahe prispiet' k objasneniu vzniku predrománskej rotundy bolo v roku 2013 naplánované ${ }^{14} \mathrm{C}$ datovanie antropogénneho kalcitu v primárnej maltovine. Stalo sa tak v rámci projektu APVV-0598-10 Archeologická chronometria na Slovensku, jedným z ciel’ov ktorého bolo zavedenie ${ }^{14} \mathrm{C}$ datovania vápenných stavebných zmesí do inštrumentária archeológie a výskumu historickej architektúry na území bývalého Československa (www.c14.sk). V súčasnosti táto prepracovaná a kredibilná metodológia (Ringbom et al. 2014), vychádzajúca z priekopníckej štúdie R. Folka a S. Valastra (Folk-Valastro 1976), predstavuje jediný spôsob ako priamo chronometricky datovat' výstavbu murív rotundy (terminus a quo). Aplikovali sme ju aj pri výskume Kostola sv. Juraja v Kostol'anoch pod Tribečom (Barta-Bóna-Keleši 2015) a keltsko-rímskych stavieb na Bratislavskom hrade (Barta-Hajnalová-Musilová 2014).

Vzorka z Rotundy sv. Juraja v Nitrianskej Blatnici (NRBLM_2), ktorú sme datovali rádiouhlíkom, bola odobratá v roku 2001. ${ }^{5}$ Pochádza zo severovýchodného obvodu lode a tvorí primárnu ložnú škárovú maltu situovanú pri vonkajšom líci múru, v úrovni $45 \mathrm{~cm}$ nad skalným podložím. V tejto časti obvodového múru lode dosahuje predstupujúce základové murivo výšku do $45 \mathrm{~cm}$, takže vzorka pochádza z najspodnejšej úrovne nadzákladového muriva (obr. 4). Chemicko-technologický rozbor primárnej maltoviny uskutočnený v roku 2009 zistil, že šedobiela jemnozrnná a vel'mi hutná malta s frakciou kremenného plniva do $0,5 \mathrm{~mm}$ obsahuje aj úlomky tehlovej hmoty a jej spojivo tvorilo dolomitické vápno (Zeman 2009, vz. 11).

Po vyseparovaní antropogénneho kalcitu z hmoty maltoviny boli z neho získané tri frakcie $\mathrm{CO}_{2}$, ktoré boli všetky datované (AMS). Prvá frakcia datuje dobu vzniku technolitu, d’alšie dve verifikujú výsledok prvého merania. Výsledok datovania prvej frakcie (AAR-18925,1: $988 \pm 26$ BP) po kalibrácii konvenčného ${ }^{14} \mathrm{C}$ veku (OxCal 4.2.4, Bronk Ramsey 2009) vyjadrujú dva disjunktné intervaly (obr. 5). Vzhl’adom na priebeh príslušnej časti kalibračnej krivky (Reimer

\footnotetext{
3 Výskum RNDr. A. Zemana, CSc., z roku 2009 bol realizovaný ako objednávka Archeologického ústavu AV ČR, Mgr. J. Maříkovej Kubkovej, $\mathrm{PhD}$., ktorej touto cestou d’akujeme za možnost' použitia výsledkov výskumu v tejto štúdii.

4 Okenné otvory u všetkých troch predrománskych stavieb sú vymurované za pomoci dreveného debnenia, ktoré zanechalo otlačky na okenných špaletách, pričom u okien kostola v Kostol’anoch pod Tribečom boli polkruhové záklenky vyskladané prečnelkovým kladením doskovitých kameňov ako u okna rotundy v Nitrianskej Blatnici (bližšie Sabadošová-Havlík 2008, 62; Dorica 2013, 64-65; Bóna 2014, 135). Napriek tejto podobnosti sa vzhl'adom na malý počet komparovatel'ných prvkov najstarších predrománskych stavieb javí ako predčasné pokladat' tento druh okna za chronologicky citlivý prvok.

5 Odber uskutočnil M. Bóna počas vyššie spomínaného prieskumu základových a soklových častí obvodových murív dňa 8. 8. 2001. Chronometrický výskum bol uskutočnený pod vedením P. Bartu v rámci grantového projektu APVV-0598-10 Archeologická chronometria na Slovensku.
} 


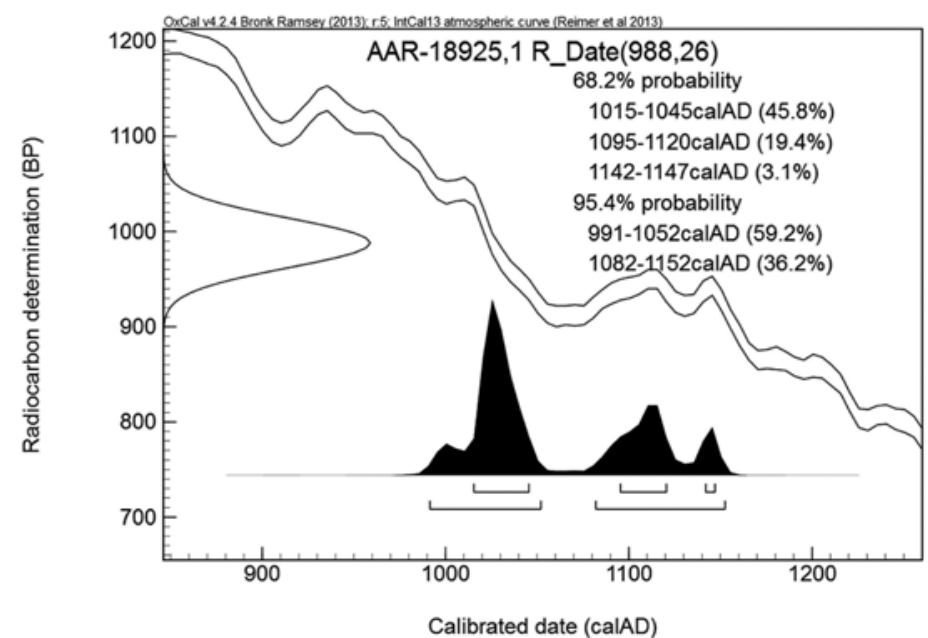

Obr. 5. Kalibrácia konvenčného ${ }^{14} \mathrm{C}$ veku prvej frakcie CO2 zo vzorky NRBLM_2, odobraté z Rotundy sv. Juraja v Nitrianskej Blatnici.

Abb. 5. Kalibrierung des konventionellen ${ }^{14} \mathrm{C}$-Alters der ersten CO2-Fraktion von der von der St. Georgsrotunde in Nitrianska Blatnica entnommenen Probe NRBLM_2.

et al. 2013) bola malta v styku s atmosférickým $\mathrm{CO}_{2}$ niekedy v rokoch 991-1052 alebo v rokoch $1082-1152$ calAD.

\section{Záver a diskusia}

Ked’že sa jedná o zatial' prvý a jediný ${ }^{14} \mathrm{C}$ dátum z objektu Rotundy sv. Juraja, je ho potrebné vnímat' ako prvý chronometrický argument v diskusii o jej datovaní, a nie ako dátum jej výstavby. Pre rozvinutie zmysluplného chronometrického výskumu je potrebné datovat' d’alšie vzorky primárnych omietok a mált, pričom prezentovaný výsledok datovania prvej vzorky poslúži pre d’alšie porovnávanie. V prípade, že sa podarí datovat' d’alšie vzorky z rotundy, bude možné sa na základe tohto výsledku vyjadrit’ k dobe jej výstavby.

Ked’že prezentovaný chronometrický výskum sa opiera o jediný ${ }^{14} \mathrm{C}$ dátum, je potrebné vzhl'adom na komplexnú povahu ${ }^{14} \mathrm{C}$ dát považovat' tento výsledok za predbežný. Výsledok zjavne nepodporuje doterajšie závery o možnej výstavbe rotundy v 9. storočí a ako najstaršiu možnost' datovania ponúka interval 991-1052 calAD.

V prípade, že by sa d’alšími meraniami potvrdila výstavba rotundy $\mathrm{v}$ intervale od konca 10. do polovice 11. storočia, neprotirečilo by to ani datovaniu najstarších hrobov cintorína rešpektujúceho rotundu, ktoré podl’a A. Ruttkaya $(1977,247)$ pochádzajú najneskôr z polovice 11. storočia. Zároveň by to otvorilo možnost' dat výstavbu rotundy do súvislosti bud' s mladšou etapou včasnostredovekého dvorca, alebo až s obdobím po jeho zániku v priebehu 11. storočia, kedy tu vzniká nevel'ké sídlisko s rozptýlenou zástavbou. Existenciu a názov osady „Sarfew“ prvýkrát uvádza testament jej majitela Stojslava z blatnicko-novosadskej vetvy Poznanovcov z roku 1185. Historik J. Lukačka sa ale domnieva, že archeologicky doložený včasnostredoveký dvorec v susedstve rotundy bol už od 10. storočia jedným zo sídiel nitrianskych Poznanovcov (Lukačka 2002, 27, 52-53).

Ďalšie prehíbenie poznatkov o dobe vzniku, pôvodnej funkcii i o stavebníkovi rotundy možno očakávat' od pokračujúceho chronometrického výskumu. 


\section{Pramene a literatúra}

Archeologická chronometria na Slovensku [on-line]. Dostupné z: www.c14.sk, cit. 4. 6. 2015.

BARTA, P.-BÓNA, M.-KELEŠI, M., 2015: Chronometrický výskum nadzemných murív Kostola sv. Juraja v Kostolanoch pod Tribečom v rokoch 2010-2014 - Die chronometrische Untersuchung der oberirdischen Gemäuer der St. Georgskirche in Kostol'any pod Tribečom aus den Jahren 2010-2014, AH 40, 691-709.

BARTA, P.-HAJNALOVÁ, M.-MUSILOVÁ, M., 2014: Rádiouhlíkové datovanie archeologických vzoriek $\mathrm{z}$ objektov z doby laténskej na Bratislavskom hrade: úvod k riadenej kalibrácii ${ }^{14} \mathrm{C}$ dát. Prednáška na konferencii „Bratislavský hrad: dejiny, výskum a obnova“, Bratislava, 22.-23. 9. 2014.

BÓNA, M., 2014: Výsledky umelecko-historického a architektonicko-historického výskumu r. k. Kostola sv. Juraja v Kostolanoch pod Tribečom. In: Musaica XXVIII. Zborník Filozofickej fakulty Univerzity Komenského, 127-161. Bratislava.

BRONK RAMSEY, CH., 2009: Bayesian analysis of radiocarbon dates, Radiocarbon 51, 337-360.

DORICA, J., 2010: Rotunda sv. Juraja vo výsledkoch reštaurátorského výskumu v roku 2009. In: Nitrianska Blatnica (Trst'an, D., ed.), 168-179. Nitrianska Blatnica.

- 2011: Reštaurovanie Rotundy sv. Juraja v Nitrianskej Blatnici v pohlade nových zistení. In: Ranostredoveká sakrálna architektúra Nitrianskeho kraja: Zborník zo seminára a katalóg ku výstave (Valeková, A., ed.), 113-128. Nitra.

- 2013: Rotunda sv. Juraja pri Nitrianskej Blatnici. Jej nové miesto medzi najstaršími sakrálnymi stavbami na Slovensku, Historická revue Špeciál, 62-67.

FOLK, R. L.-VALASTRO, S., 1976: Successful Technique for Dating of Lime Mortar by Carbon-14, Journal of Field Archaeology 3, 203-208. DOI: 10.2307/529387

FORSTER, Gy., ed., 1906: Magyarország müemlékei II. Budapest.

LUKAČKA, J., 2002: Formovanie vyššej šlachty na západnom Slovensku. Bratislava.

REIMER, P. J. et al., 2013: Reimer, P. J.-Bard, E.-Bayliss, A.-Beck, J. W.-Blackwell, P. G.-Bronk Ramsey, C.-Grootes, P. M.-Guilderson, T. P.-Haflidason, H.-Hajdas, I.-Hatte, C.-Heaton, T. J.-Hoffmann, D. L.-Hogg, A. G.-Hughen, K. A.-Kaiser, K. F.-Kromer, B.-Manning, S. W.-Niu, M.-Reimer, R. W.Richards, D. A.-Scott, E. M.-Southon, J. R.-Staff, R. A.-Turney, C. S. M.-Van Der Plicht, J., IntCal13 and Marine13 radiocarbon age calibration curves 0-50,000 years cal BP, Radiocarbon 55, 1869-1887.

REJTHAR, R., 1975: Nitrianska Blatnica, Rotunda sv. Juraja. Zámer pamiatkovej úpravy, ulož. v Ústrednom archíve PÚ SR v Bratislave, sign. T 5124.

RINGBOM, A. et al., 2014: Ringbom, A.-Lindroos, A.-Heinemier, J.-Sonck-Koota, P., 19 years of mortar dating: learning from experience, Radiocarbon 56, 619-635. DOI: 10.2458/56.17469

RUTTKAY, A., 1977: Výskum zaniknutého včasnostredovekého sídliska, architektúry a pohrebiska pri Nitrianskej Blatnici v roku 1976. In: AVANS 1976, 243-251. Nitra.

- 1978: Nitrianska Blatnica. In: Významné slovanské náleziská na Slovensku (Chropovský, B., ed.), 143144. Bratislava.

- 1980: Výsledky výskumu v Nitrianskej Blatnici v roku 1979. In: AVANS 1979, 185-191. Nitra.

- 1989: Nitrianska Blatnica. In: Pramene k dejinám osídlenia Slovenska z konca 5. až z 13. storočia, I/2 (Bialeková, D., ed.), 347-348. Nitra.

- 1998: Zur frühmittelalterlichen Hof-, Curtis und Curia regalis - Frage in der Slowakei. In: Frühmittelalterlicher Burgenbau in Mittel- und Osteuropa (Henning, J.-Ruttkay, A. T., edd.), 405-417. Bonn.

- 2005: Sídla spoločenských elít na strednom Ponitrí v 9.-13. storočí. In: Ruttkay, M., Dávne dejiny Nitry a okolia, 77-90. Nitra.

- 2011: Najstaršie sakrálne stavby na území Nitrianskeho samosprávneho kraja vo svetle archeologických výskumov. In: Ranostredoveká sakrálna architektúra Nitrianskeho kraja. Zborník zo seminára a katalóg ku výstave (Valeková, A., ed.), 39-58. Nitra.

- 2013: Včasnostredoveký sídliskový komplex a Rotunda sv. Juraja pri Nitrianskej Blatnici, Historická revue Špeciál, 55-61.

SABADOŠOVÁ, E.-HAVLÍK, M., 2008: Kopčany - Kostol sv. Margity Antiochijskej. Umelecko-historický výskum južnej a západnej fasády lode kostola s vyhodnotením reštaurátorských nálezov počas odstraňovania omietok, ulož. v Archíve KPÚ v Trnave.

SÚPIS 1968: Súpis pamiatok na Slovensku. Zv. II. Bratislava.

ZEMAN, A., 2009: Výsledky výzkumu malt z kostela sv. Juraja z Kostolan pod Tribečom. Brandýs nad Labem, ulož. v archivu ARÚ AV ČR, Praha, v. v. i. 


\section{Zusammenfassung}

\section{Ein Beitrag zur Datierung der Entstehung der St. Georgsrotunde in Nitrianska Blatnica}

Die vollständig erhaltene St. Georgskirche liegt 3,5 km nördlich von Nitrianska Blatnica auf einem Bergsporn namens Jurko (455 m. ü. M.). Den bisherigen Forschungen zufolge besteht ihr ältester vorromanischer Teil aus einem zentralen zylinderförmigen Schiff und einer Ostapsis mit halbkreisförmig verlängertem Grundriss (Abb. 2). In der Neuzeit wurde ein Quaderturm und ein als Klause dienener Südanbau angebaut. Durch die in den Jahren 1974-1980 erfolgten Grabungen wurde belegt, dass es spätestens um Mitte des 11. Jahrhunderts zum Bau der Rotunde gekommen sein muss. Vom damaligen Grabungsleiter A. Ruttkay wird jedoch angenommen, dass die Entstehung der Rotunde bereits mit den Anfängen des dortigen Meierhofs aus dem 9.-10. Jahrhunderts zusammenhängt. Seine Behauptung stützt er dabei auf die bauliche Analogie zu dem nahegelegenen großmährischen Meierhof mit Rotunde in Ducové und auf die archaische Form eines Originalfensters, das formenmäßig mit den Fenstern der vorromanischen Kirchen in Kostolany pod Tribečom und in Kopčany verwandt ist.

In dem Bestreben, zur Klärung der Entstehung der vorromanischen Rotunde einen weiteren Beitrag zu leisten, wurde im Jahr 2013 eine ${ }^{14} \mathrm{C}$-Messung des anthropogenen Calcits des Primärmörtels durchgeführt. Die untersuchte Probe stammt aus dem Mauerwerk der Westfassade des Schiffs (Abb. 4). Die Ergebnisse der Datierung des anthropogenen Calcits lassen sich durch zwei unterschiedliche Intervalle wiedergeben: 991-1053 und 1081-1154 calAD (Abb. 5). Im Hinblick darauf, dass es sich um die erste ${ }^{14} \mathrm{C}$-Datierung des Primärmörtels handelt, muss dieses Ergebnis als vorläufig angesehen werden.

Die ermittelte Datierung des Abbindezeitpunkts des Primärmörtels stützt die von der bisherigen Forschung getroffenen Schlussfolgerungen bezüglich eines möglichen Baus der Rotunde im 9. Jahrhundert nicht. Als älteste Datierungsmöglichkeit bietet das Datierungsergebnis ein Zeitintervall an, das zwischen Ende 10. und Mitte 11. Jahrhundert liegt. Das ermöglicht es, den Bau der Rotunde vorläufig nur mit der jüngsten Etappe des benachbarten frühmittelalterlichen Meierhofs oder erst mit dem Zeitraum nach dessen Untergang im 11. Jahrhundert in Verbindung zu bringen, als bei der Rotunde eine kleinere Siedlung mit verstreuter Bebauung entstand. Die Existenz und der Name der Siedlung „Sarfew“ findet erstmals 1185 im Testament ihres Eigentümers Stojslav von dem Zweig der Adelsfamilie Poznan Erwähnung, der in Blatnica-Novosad ansässig war. Eine weitere Vertiefung der Erkenntnisse über Entstehungszeit, ursprüngliche Funktion sowie die Bauherren der Rotunde können von der noch laufenden chronometrischen Untersuchung erwartet werden.

Die Entstehung der vorliegenden Arbeit wurde von der Agentur zur Förderung von Forschung und Entwicklung auf Grundlage des Vertrags Nr. APVV-0598-10 gefördert.

Ing. arch. Martin Bóna, PhD., ProMonument s.r. o., Štefánikova 14, SK 95301 Zlaté Moravce, Slovenská republika,bona.martin@gmail.com

Mgr. Peter Barta, PhD., Katedra archeológie Filozofickej fakulty Univerzity Komenského v Bratislave, Gondova 2, SK 81499 Bratislava, Slovenská republika, peterbarta@chello.sk 
